\title{
Asset choice in British central banking history, the myth of the safe asset, and bank regulation
}

\author{
William A. Allen ${ }^{1}$ \\ Cass Business School, London, United Kingdom \\ E-mailbill@allen-economics.com
}

Received: 28 January 2015 / Revised: 24 April 2015 / Accepted: 21 May 2015 / Published online: 2 June 2015

\begin{abstract}
The paper describes the use of commercial bills in Bank of England open-market operations from the earliest days of central banking in the $19^{\text {th }}$ century, when, it is suggested, the Bank of England's main objective was what would now be called macro-prudential, until the 1980s, when commercial bill purchases were an essential feature of contemporary anti-inflationary policy. It explores the relationship between government securities, central bank assets and bank liquidity regulation, exposes as a myth the belief that government securities are perfectly safe assets, and challenges the idea that central banks should confine their asset holdings to government securities. In addition, the paper argues that by making more active use of the policy instrument of central bank asset choice, by acknowledging the connection between liquidity regulation and open-market operations, and by making certain changes to the Basel 3 Liquidity Coverage Ratio regulations, central banks could both better achieve some of their macro-prudential policy objectives and stimulate high-quality bank lending.
\end{abstract}

\section{JEL classification: E52, E58}

Keywords: commercial bills, bills of exchange, Bank of England, eligibility, bank liquidity, Basel 3, Liquidity Coverage Ratio, overfunding, monetary targets, macroprudential policy, risk-free asset, government securities.

\section{INTRODUCTION}

The paper is organised as follows. Section 2 is a historical account of the use of commercial bills as assets of the Bank of England since the $19^{\text {th }}$ century, set in the context of the objectives of public policy and of the Bank of England as it developed into a central bank in the second half of the century. Section 3 discusses central bank asset choices in today's financial environment, and demonstrates that new post-crisis liquidity regulation needs to be consistent with central banks' eligibility policies. It attacks the view that central bank assets should be limited to domestic government securities, and shows that liquidity regulation has created a bias in favour of lending to governments. Section 4 briefly summarises the conclusions.

Based on a paper presented at the Round Table of the European Central Bank Committee on Financial Integration, $7^{\text {th }}$ July 2014. I am grateful to Bernhard Winkler, Hans-Helmut Kotz and other participants in the Round Table, to Richhild Moessner and to an anonymous referee, for extremely helpful comments on earlier versions. I am also grateful to Edward Nelson, Clifford Smout and John Whittaker for useful discussions on the subject matter. None of them is responsible for the views expressed in the paper, or for the paper's shortcomings. 


\section{COMMERCIAL BILLS AND CENTRAL BANKING IN BRITAIN}

Bills of exchange first appeared in Europe in the thirteenth century, in Genoa, Florence and Venice, and penetrated trade thereafter, if only slowly; 'there can be little doubt of the essential perfection of the bill by $1650^{\prime}{ }^{2}$ Bills therefore have a much longer history than any central bank. They were widely used in England in the $19^{\text {th }}$ century, in a period when banks were largely local organisations, as a vehicle for financial intermediation between the agricultural parts of the country, where the banks typically had excess funds, and the industrial districts, where the banks were typically short of funds. Industrial borrowers would draw bills which their local banks would accept, and the bills found their way, often via the London bill brokers, to the banks in rural areas. They sometimes circulated as means of payment. ${ }^{3}$ Later in the $19^{\text {th }}$ century, the use of bills in domestic trade declined, but commercial bills were increasingly used for financing international trade.

Table 1

Relevant events in British monetary history

\begin{tabular}{|c|c|}
\hline 1797 & Suspension of gold convertibility of Bank of England notes. \\
\hline 1821 & Resumption of gold convertibility after Napoleonic Wars. \\
\hline 1825 & Financial crisis following collapse of stock market boom. \\
\hline 1844 & Bank Charter Act, regulating Bank of England note issue. \\
\hline 1847 & Financial crisis following harvest failure and the end of the railway boom. \\
\hline 1857 & Financial crisis originating in the United States. \\
\hline 1858 & Withdrawal of Bank of England from money market dealing. \\
\hline 1866 & $\begin{array}{l}\text { Financial crisis following the failure of Overend \& Gurney, which was not rescued by Bank } \\
\text { of England. }\end{array}$ \\
\hline 1873 & $\begin{array}{l}\text { Publication of Walter Bagehot's 'Lombard Street', advocating larger gold reserves and last resort } \\
\text { lending by Bank of England in case of need. }\end{array}$ \\
\hline 1878 & Bank of England resumed routine lending to money market. \\
\hline 1890 & Baring crisis: Barings were rescued by a group of banks led by the Bank of England. \\
\hline 1890 & $\begin{array}{l}\text { Bank of England resumed routine bill discounts for money market and began to build up gold } \\
\text { reserves. }\end{array}$ \\
\hline $1914-1918$ & $\begin{array}{l}\text { Outbreak of war in } 1914 \text { caused immediate banking crisis. The war led to a massive enlargement } \\
\text { of government debt. }\end{array}$ \\
\hline 1931 & Banking crisis originating in Austria, Hungary and Germany. \\
\hline 1939-1945 & War and further massive enlargement of government debt. \\
\hline $1981-1985$ & $\begin{array}{l}\text { 'Overfunding' of government deficit accompanied by Bank of England commercial bill purchases } \\
\text { was used as a technique for reducing inflation. }\end{array}$ \\
\hline 2009-2012 & Quantitative easing, i.e. heavy purchases of government securities by Bank of England. \\
\hline
\end{tabular}

Once the convertibility of Bank of England notes into gold had been restored in 1821, after the Napoleonic Wars, price stability was not a policy concern (it was taken care of by the gold standard); nor was full employment. ${ }^{4}$ Two leading concerns of British monetary policy were, first, to manage the periodic financial crises $(1825,1847,1857,1866)$ that occurred, and second, to find

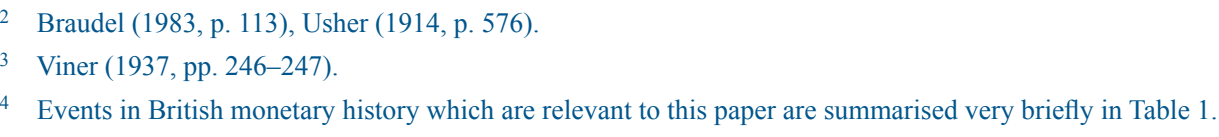


a means of preventing them. The latter concern might now be described as 'macro-prudential', since crisis prevention is the purpose of macro-prudential policy. At the time, the immediate concern was to protect the Bank of England's gold reserves, but since in practice the main threat to the gold reserves came from excessive credit expansion, which led to financial crises and surges in the demand for gold, crisis prevention and protection of the gold reserves amounted to much the same thing. Consequently the monetary history of $19^{\text {th }}$ and early $20^{\text {th }}$ century Britain is relevant to present-day debates on macro-prudential policy. It was in the second half of the $19^{\text {th }}$ century that the Bank of England consciously took on the responsibilities now associated with a central bank, rather than being managed exclusively for the benefit of its proprietors.

The Bank Charter Act of 1844 was intended to prevent crises by ensuring that the Bank of England's note issue would be managed in accordance with the principles of the Gold Standard. The note issuing activities of the Bank had to be reported in a separate weekly account (the Issue Department) and notes issued had to be matched one for one by holdings of bullion, valued at the mint price, with the exception of a fixed fiduciary issue backed by government securities. The banking activities of the Bank were reported in a separate account (the Banking Department), and the Banking Department 'should be governed on precisely the same principles as would any other Body dealing with Bank of England notes', according to Sir Robert Peel, the promoter of the 1844 Act. $^{5}$

Bills discounted were an important component of the Bank of England's assets in the $19^{\text {th }}$ century, as Table 2 shows, and they accounted for a substantial proportion of its income. ${ }^{6}$ Many of the Bank of England's advances (also shown in Table 2) will also have been against the security of bills. Moreover, discounts and advances were among the most volatile components of the Banking Department's assets, at least after the middle of the $19^{\text {th }}$ century: the average absolute monthly changes in discounts and advances were $18 \%$ and $30 \%$ respectively of the average amounts in the portfolio, compared with, for example, just 3\% in the case of 'other securities', which averaged $23 \%$ of the stock of total assets and were held for income generation purposes. The Bank of England was choosy in discounting: in the early $19^{\text {th }}$ century it would not discount paper longer than 65 days, and it insisted on 'two good London names', i.e. endorsements, but that was probably for commercial rather than public policy reasons. ${ }^{7}$

Table 2

Discounts and advances in the Banking Department's balance sheet, 1851-1914

( $£ 000$ s, percentages in brackets, averages)

\begin{tabular}{lccc}
\hline \hline & Discounts & Advances & Total assets \\
\hline July 1851-1859 & $5,833(16)$ & $1,004(3)$ & 36,889 \\
$1860-1869$ & $7,130(18)$ & $1,984(5)$ & 40,516 \\
$1870-1879$ & $4,907(10)$ & $3,404(7)$ & 47,233 \\
$1880-1889$ & $1,690(3)$ & $4,859(10)$ & 49,117 \\
$1890-1899$ & $3,703(6)$ & $11,136(18)$ & 62,688 \\
$1900-1909$ & $6,214(9)$ & $11,427(16)$ & 71,430 \\
$1910-J u n e ~ 1914$ & $8,128(11)$ & $8,629(11)$ & 76,360 \\
\hline \hline
\end{tabular}

Source: Bank of England archives, file numbers $\mathrm{C} 1 / 113, \mathrm{C} 1 / 1-1 / 62$. The data shown are averages of data from the last Wednesday of each month, except that where the last Wednesday of the month was a holiday, the data from the next working day was used.

\footnotetext{
Quoted by Gregory (1929, p. xxv).

For the contribution of discounts to income, see Clapham (1944, vol. 2 Appendix C and D).

See for example Clapham (1944, vol. 2, p. 135)
} 
The Bank Charter Act did not bring an end to financial crises, and pressure developed for the Bank of England (Banking Department) to act in the public interest, by achieving the crisis prevention objectives that the Bank Charter Act had not secured, and by managing crises if they could not be prevented. ${ }^{8}$ Bagehot's famous book 'Lombard Street', first published in 1873, advocating larger gold reserves and last-resort lending, is perhaps the best-known example of such pressure. And, indeed, the Bank of England acceded to the pressure, building up its reserves and accepting responsibility for the stability of the banking system, notably, for example, in its management of the Baring crisis of $1890 .^{9}$

The banking industry grew very fast in the second half of the $19^{\text {th }}$ century. The Bank of England did not keep pace and lost its earlier source of market power, namely its sheer size, but it developed a new source of power, namely the commercial banks' dependence on it for liquidity. It was helped in this by the commercial banks' practice of 'window dressing' their balance sheets to make them appear more liquid than they actually were; this meant that the money market needed cash from the Bank of England at the end of each quarter, when banks had to report their assets on the same day. And, in the late $19^{\text {th }}$ and early $20^{\text {th }}$ century, the Bank went out of its way to borrow money from commercial banks, from the Stock Exchange, from the Council of India and from the Japanese government, in order to increase the money market's dependence on it for liquidity and its ability to control short-term interest rates. ${ }^{10}$ It thereby increased the amount of bullion that it held in excess of the amount required to support the stock of banknotes demanded by the public; the excess was represented by banknotes held in the Banking Department, which were supported by bullion held in the Issue Department, and by moderate amounts of bullion held in the Banking Department (Figure 1).

\section{Figure 1}

Banking Department assets and notes outside the Bank of England, 1851-1914 (£000s)

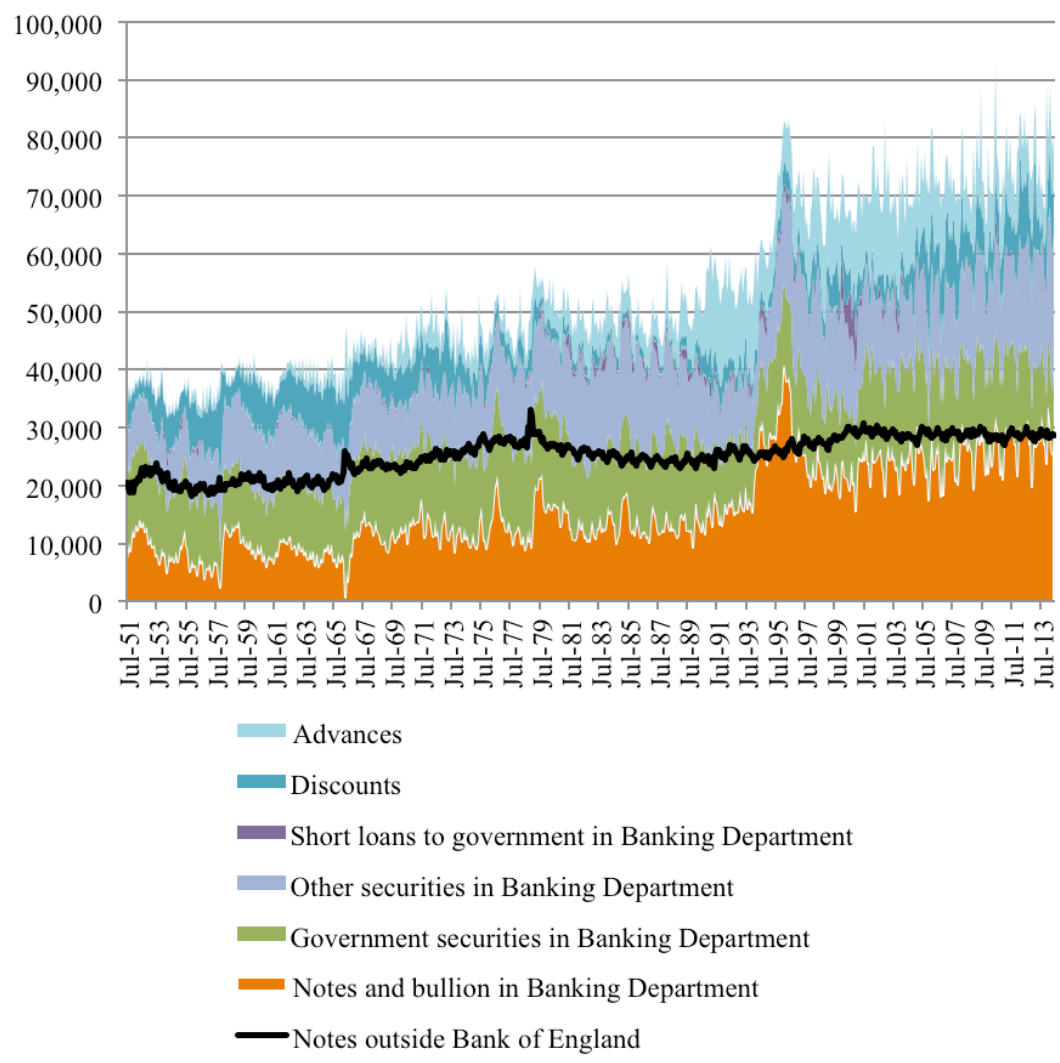

Source: Bank of England Archive, Daily Account Books (one day from each month).

See e.g. Whale (1944).

See Clapham (1944, vol. 2, pp. 326-339), Ziegler (1988, chapter 14).

10 Sayers (1936, chapter II), Sayers (1957, chapter 2), King (1972, pp. 313-314). 
In the crisis of 1857, the Bank of England lost large amounts of gold as the demand for liquidity surged, and the gold standard had to be suspended. The Bank of England's initial reaction, in 1858, was to withdraw from the market: it abandoned the practice of routine discounting for 'bill brokers, money dealers and discount companies', and would lend and discount only at times of general stringency. In 1878, however, it announced that 'at this penal rate [Bank rate] or thereabouts, it would lend to the market, not only at times of crisis, but as a general rule. It would not discount bills outright, but would make advances to bill-brokers and discount companies.' ${ }^{11}$ In 1890 it resumed the routine discounting of bills for the market. Only very short bills were initially eligible, but the rules were later relaxed and by 1897 the limit was three months. ${ }^{12}$ There are signs that the Bank used its power to pursue what would now be called macro-prudential objectives: in 1905 - 07, as a boom developed in the United States, it signalled to London banks, 'mainly by its selectivity in discounting bills - that they should cut down commitments to finance speculation in New York'. ${ }^{13}$ Admittedly it was motivated partly by a desire to protect its gold reserve, but its action also had a macro-prudential aspect.

After the First World War, the Bank of England was concerned about the explosion of the 'floating debt' of the government (i.e. Treasury bills and Ways and Means Advances from the Bank to the government), which had risen from $£ 13$ million at the end of March 1914 to $£ 1,412$ million (25\% of GDP) five years later. ${ }^{14}$ The Bank of England considered this to be a seriously unsound method of financing the government and, in a vain attempt to discourage it, demonstrated a preference for high-quality commercial bills over Treasury bills in its open-market operations immediately after the war. ${ }^{15}$

The Bank also concerned itself with the quality of commercial credit in the bill market. It 'would be seeking to discourage some classes of business in the market generally, and it would be watching to see that particular firms avoided objectionable paper'. ${ }^{16}$ It expressed its concern by refusing to discount commercial bills which failed to meet its minimum standards, thereby ensuring that they could not trade at the finest rates in the market. It should be noted, however, that bills accounted for just $17 \%$ of banks' commercial assets in 1920, and that the percentage had fallen to $12 \%$ by $1928 .{ }^{17}$ The macro-prudential ambitions of the Bank of England were thus confined to the bill market and there was no official oversight of the totality of the commercial banks' assets. ${ }^{18}$

The failure of the supply of Treasury bills to contract, as the Bank of England had wished, and the decline in the supply of commercial bills as international trade collapsed during the Great Depression, meant that the Bank of England's open-market operations came to be dominated by Treasury bills, and its dealings in commercial bills were for many years reduced to 'sampling' - in other words, regular purchases of small parcels of bills for the express purpose of monitoring their quality. The 1930s were one of the few periods in British monetary history in which the supply of bank credit was clearly inadequate, and Bank of England policy did little to help. ${ }^{19}$ Fortunately, the 'cheap money' policy instituted in 1932, together with the remarkable expansion of mortgage credit provided by building societies, mutual institutions which were the 'shadow banks' of

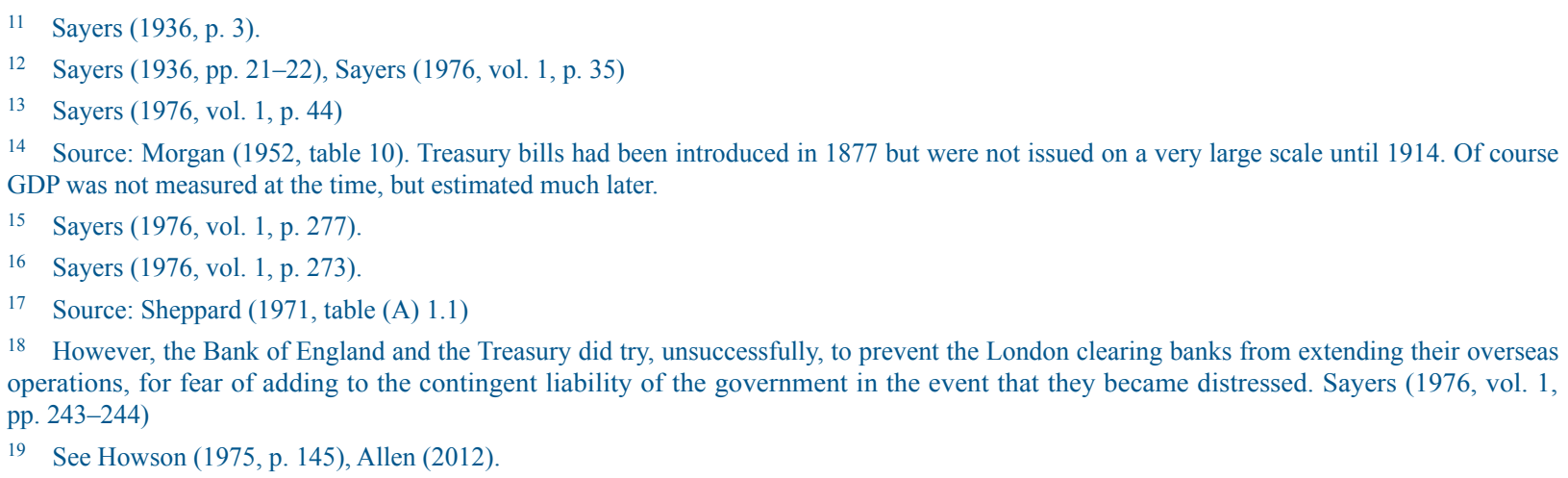


that era, facilitated a housebuilding boom which greatly alleviated the depression in many parts of the U.K. ${ }^{20}$

The supply of Treasury bills exploded again during and after the Second World War, and the Bank of England's purchases of commercial bills remained confined to sampling until the early 1980s. Inflation had got badly out of control in Britain in the 1970s and the government turned in desperation to monetary targets in the hope of salvation. The target they chose was for broad money (M3, later its sterling component known as sterling M3). Broad money was not very susceptible to control by variations in short-term interest rates, largely because much of it consisted of wholesale bank deposits which bore interest at market-related rates. It was however somewhat susceptible to variations in the government's debt management policy. Lengthening the maturity of the government debt by selling more bonds (gilts) absorbed bank deposits and contained the growth of broad money. The strategy of 'overfunding' - selling more gilts than were needed to meet the government's deficit - was implemented from 1981/82 until 1984/85. Of course, this made the banking system chronically short of funds. The initial effect was that the supply of Treasury bills dried up: the Bank of England bought nearly all the existing bills in its open market operations, and the new supply was reduced to a minimum. Soon, the Bank needed to buy assets from the commercial banks to keep them supplied with liquidity and to offset the drain created by the policy of overfunding.

The preferred asset was commercial bills. This reflected their several attractions: 'they gave security in depth, in that they bore at least two good "names", and their creditworthiness had been assessed before they reached the Bank, notably by the acceptor when taking on the commitment. 21 The two names were those of the accepting bank and of the discount house which sold the bill to the Bank. In order for the Bank to lose money, the original drawer, the acceptor and the discount house would all have had to fail (along with any intermediate holders). And commercial bills had a codified legal foundation in the Bills of Exchange Act 1882, as subsequently amended. The main uncertainty was whether the market could generate enough bills to meet the Bank's unpredictable but growing needs. The Bank used supplementary techniques: purchases of local authority bills, and at periods of particular stress, repos of government-guaranteed export credit and shipbuilding assets with the commercial banks. It also considered buying certificates of deposit issued by commercial banks, but never did so. ${ }^{22}$

In the event, the market did generate enough eligible commercial bills (see Figure 2). The supply of commercial bills increased from $4.5 \%$ of the banks' sterling assets in October 1980 to $8.4 \%$ in April 1982. The surge in the Bank of England's demand for bills caused their yields to fall relative to inter-bank deposit rates (see Figure 2), initially to about 40 basis points below interbank rates, though the margin gradually narrowed. The Bank required that all the bills it bought met its minimum quality standards, which were intended to ensure that they could reasonably be described as financing short-term self-liquidating transactions. The required standards were described to the market, though not precisely specified, in August and November 1981 in 'aidesmemoire'. Bills purchased were inspected and those that were deemed unsatisfactory were returned. It is fair to say that fine judgments were often required as to the eligibility of particular bills. The Bank's practices as regards eligibility had to be adapted as market practices and trading practices evolved. The Bank was normally willing to buy bills with up to 3 months to maturity, and at times of stress it undertook repo operations with the market in which bills with up to 6 months to maturity were eligible.

\footnotetext{
20 Building society mortgages outstanding increased by $£ 438$ million in the 1930 s, an annual average growth rate of $11.5 \%$. The annual average increase in outstanding mortgages was equivalent to $0.9 \%$ of GDP. The building societies appear to have been uninhibited by concerns about liquid asset ratios: the ratio of cash and investments to total assets fell from 14.3\% to 8.7\% during the 1930s. Source of data: Sheppard (1971, table (A) 2.4).

21 Coleby (1982, p. 515).

22 Coleby, 'Overfunding: implications for money market operations', $5^{\text {th }}$ November 1981, Bank of England archive document, file number 2A182/3.
} 
Figure 2

Commercial bill quantities and yield margins, 1979-1991

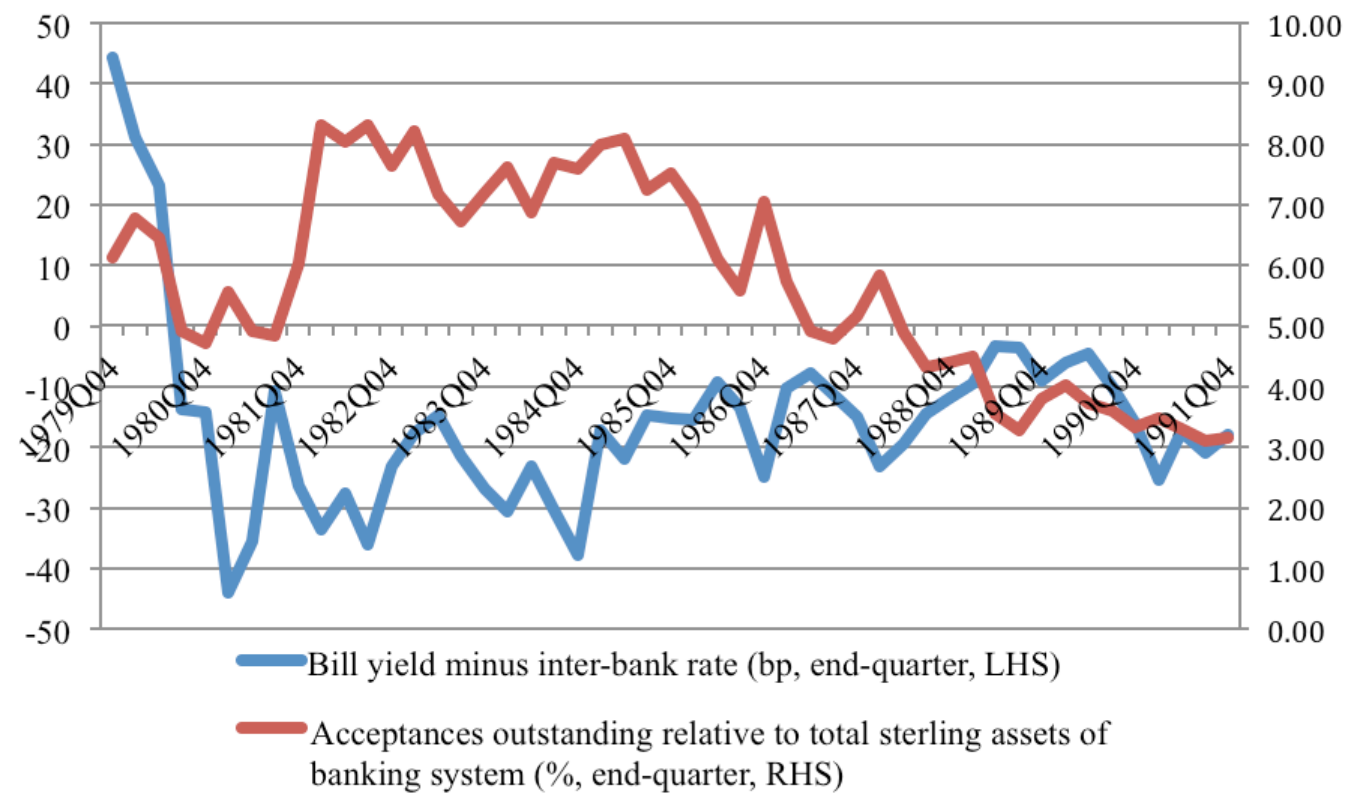

The Bank maintained a list of commercial banks whose acceptances were eligible for rediscount; the list was regularly reviewed and updated. The Bank imposed an upper limit on its bill market exposure to each accepting bank. As the implementation of monetary policy required the Bank to hold progressively larger amounts of commercial bills, the limits had to be gradually increased; in effect, they were limits on each bank's share of the commercial bill market. The limits were enforced not by rejecting bills which would have taken the Bank's holdings of an individual acceptor's bills above the limit but by inviting the acceptor concerned to place fewer bills in the market. The Bank lost no money in this period as a result of dishonoured bills.

The use of commercial bills in Bank of England operations declined in the 1990s, especially after the introduction of a gilt repo market in 1997, and the market atrophied. Commercial bills ceased to be eligible for rediscount in 2005.

It is perhaps worth adding that the Federal Reserve, immediately after it had been established, made it a policy objective to develop a commercial bill market in the United States. It succeeded for a period, but the market shrivelled in the 1930s, both because of the Great Depression and because the Fed withdrew after the passage of the Glass-Steagall Act relaxed the constraints on its ability to purchase government debt. ${ }^{23}$

\section{CENTRAL BANK ASSET CHOICE TODAY, LIQUIDITY REGULATION AND THE SAFE ASSET MYTH}

For the most part, central bank's domestic asset portfolios were dominated by government securities for half a century or more after the end of the Second World War, the Bank of England's commercial bill purchases in the 1980s being a rare exception. However, in the financial crisis that began in 2007, central banks greatly widened the range of assets that they were willing to buy or accept as collateral for loans. In deciding which new assets to accept, they were no doubt, and understandably in the circumstances, motivated mainly by the range of assets that the banks had to offer.

23 See Eichengreen and Flandreau (2010), Meulendyke (1998), Stella (2009), Warburton (1952). For a broader historical survey of the relationship between market structures and monetary policy, see Jobst and Ugolini (2014). 
In the wake of the crisis, central banks are faced with new challenges. One is to stimulate the supply of bank credit where it has dried up. Mortgage credit has generally remained available, helped by the willingness of the European Central Bank and the Federal Reserve to buy mortgagebacked securities or take them as collateral, and by low regulatory risk weights. Large companies may have direct access to capital markets and therefore not be much affected by any interruption to the supply of bank credit. But small and medium-sized companies in particular face difficulty in getting credit from banks.

Another challenge for central banks is to find ways of implementing macro-prudential policy - or, to be more specific, of achieving macro-prudential policy objectives, which include the avoidance of another credit boom financed by banks which results in taxpayers being required to put up capital to prevent bank failures.

The supply of bank credit in Britain has been impeded, at least temporarily, by the introduction of tighter regulation of bank liquidity, as provided for in Basel 3 by the Liquidity Coverage Ratio (LCR) and the Net Stable Funding Ratio. The LCR requires banks to hold specified liquid assets sufficient to provide for a hypothetical liquidity crisis lasting a month. The requirement will not become effective until 2019, but banks, under pressure from investors and perhaps also regulators, have anticipated it. The specified liquid assets that banks have to hold are mainly deposits in central banks and government securities (level 1 liquid assets). However, up to 40\% of the requirement may be met with holdings of specified private assets (level 2), which 'have a proven record as a reliable source of liquidity in the markets (repo or sale) even during stressed market conditions'. Level 2 assets are subject to a discount in the LCR calculation. ${ }^{24}$

The intensification of liquidity regulation since the onset of the financial crisis, the introduction of the LCR, and above all the strong preference of regulators for government securities as liquid assets, has introduced into bank credit markets a new bias in favour of government borrowers and against commercial borrowers. In the U.K., commercial banks lent $£ 419$ billion (roughly a quarter of a year's GDP) net to the government and the Bank of England between the end of 2006 and the end of 2013, while loans to non-financial companies declined by $£ 87$ billion.

Eligibility policy is a weapon which central banks could use in pursuit of both credit supply and macro-prudential objectives. This weapon has been widely used since the financial crisis in the attempt to keep credit flowing, but it has been used passively: in order to keep commercial banks liquid, central banks appear to have taken the best (or least bad) assets that the commercial banks (and, in the United States, broker-dealers) happened to have, rather than the assets that they wanted.

The United Kingdom has been an exception, in that the Bank of England's large-scale asset purchases have been mainly of government securities. ${ }^{25}$ The reason for this concentration was not macro-prudential, but rather a conviction that it is not the proper business of central banks to hold commercial assets. This conviction may rest on one or both of the following foundations.

a. The belief that government securities, or at least those that are denominated in domestic currency, are safe assets, in that they carry no default risk. One possible reason for thinking that they carry no default risk is that the belief (i) that if the government gets into financial difficulty, it will always have a choice between default and inflation, and (ii) that, faced with the choice, it will always choose inflation as the lesser evil. Neither of these beliefs is sustainable. Governments of countries in monetary unions, such as those in the euro area, do not have a choice between default and inflation. And even in countries which are not in monetary unions, and which do have such a choice, governments may default rather than inflate their domestic currency debts away. Russia did so in 1998, and the United

Basel Committee on Banking Supervision (2013, pp. 11-13).

25 The emergency loans made to Royal Bank of Scotland and Halifax Bank of Scotland in 2008 are exceptions, as is the Special Liquidity Scheme of 2009-2012 and the more recent Funding for Lending scheme (see Churm, Radia, Leake, Srinavasan and Whisker 2012). Quantitative easing as practised by the Bank of England does not add directly to the supply of level 1 liquid assets; it merely exchanges one level 1 liquid asset for another. 
States Congress has on several occasions delayed approving increases in the Federal debt limit, threatening to put the United States Treasury into a position where it could not avoid defaulting on its debt. Moreover the Greek election result of January 2015 shows that, in a democracy, a government may be elected with a mandate not to observe the terms of previously-contracted debts. The fact that no government can bind its successors is a fundamental weakness of government securities of all kinds.

Domestic-currency government securities cannot, therefore, be regarded as perfectly-safe assets. The widespread contrary belief, which is enshrined in the specification of the LCR and in the risk weights used for calculating bank capital requirements, perhaps reflects the many years of experience after 1945, when central banks were mainly dominated by their national governments and were not constrained by the gold standard or otherwise from creating as much money as was necessary to pay the government's debts, and when legislators were not inclined to force their executives either to limit borrowing or to default.

b. The notion that purchases of commercial assets are acts of fiscal policy which are outside the proper province of an independent central bank, and that official purchases of commercial assets ought to be conducted by agencies subject to democratic control (Goodfriend 2011, Buiter 2014). The then Bank of England Governor Sir Mervyn King appeared to endorse this view when giving evidence to the House of Commons Treasury Committee in 2012. ${ }^{26}$ However, it has no foundation in historical central banking practice, which has tended to prefer commercial assets and to be suspicious of central banks financing governments. ${ }^{27}$ Moreover it is impractical. Most central banks hold foreign reserve assets, which are necessarily in the form of financial claims on foreigners - either banks or issuers of securities. And in some happy countries, there is simply too little government debt to satisfy the need of the central banks for assets to back the note issue.

Leaving these impracticalities aside, the 'democratic control' argument for a government securities-only policy on the part of central banks is an extreme one. Central banks are typically owned by governments, and have capital provided by governments in their capacity as shareholders. Their capital is limited, and therefore their capacity to buy commercial assets prudently is also limited. Governments may oversee the asset-purchasing policies of central banks, and their profitability, in their capacity as shareholders, and this might be thought sufficient for democratic control purposes, particularly when considered in combination with scrutiny of the central bank by the legislature.

One of the practical consequences of the application of the government securities-only policy in the United Kingdom has been to contribute to the heavy but hidden subsidy to government borrowing, and to the weakness in bank lending to the private sector.

Eligibility policy has not been used much, if at all, for macro-prudential purposes in recent years. Rather, it has been used to support the supply of credit. Nevertheless, Galati and Moessner, in their survey (2013) of the literature on macro-prudential policy, include collateral policies (which are the same as what I call eligibility policies) in their list of available tools to foster financial stability (their table 2), but under the heading of monetary rather than macro-prudential policy. However, the distinction which has largely been maintained both in academic literature and in the organisational structures of central banks between monetary and macro-prudential policy is a distinction without a difference, as it was in the late- $19^{\text {th }}$ and early- $20^{\text {th }}$ centuries. Eligibility policy and bank liquidity regulation could be designed much more effectively than at present for both credit supply and macro-prudential purposes.

The LCR creates a category of assets which are privileged in that banks are required to hold minimum quantities of them; as a result, they yield less than other bank assets. As already noted,

26 House of Commons Treasury Committee (2012).

27 This suspicion is most evident in the statues of the European Central Bank, which forbid the practice. 
there are also 'level 2' liquid assets allowed under the LCR: they are subject to a discount, and after the discount, may account for a maximum of $40 \%$ of the liquidity requirement, so they are much less privileged than the 'level 1' assets, which are claims on the public sector. It has already been noted that 'level 1' assets are not completely safe. Moreover, the private assets selected for level 2 are a curious collection. They include, for example, certain non-financial corporate debt securities, including commercial paper, and covered bonds, which are highly-rated, 'traded in large, deep and active cash or repo markets characterised by a low level of concentration'. These are typically assets which are liquid in normal market conditions, but perhaps not all: it is possible to imagine market conditions in which even the finest corporate or covered bonds would be hard to sell. It cannot be said that commercial bills are liquid in all conditions, but at least their short maturity provides protection against illiquidity that is not available to, say, a corporate bond.

The LCR adds to the cost of making commercial loans. If:

$\mathrm{r}_{\mathrm{D}} \quad$ is the interest rate on deposits;

$\mathrm{r}_{\mathrm{L}}$ is the yield of the level 1 liquid assets that the banks are required to hold; it can safely be assumed that $\mathrm{r}_{\mathrm{L}}<\mathrm{r}_{\mathrm{D}}$;

$\mathrm{r}_{\mathrm{N}} \quad$ is the interest rate on the safest of commercial loans which are not counted as liquid assets for LCR purposes; and

$\theta \quad$ is the percentage level 1 liquidity requirement;

then $r_{N}=\left(r_{D}-\theta r_{L}\right) /(1-\theta)$, ignoring the bank's cost of capital and management (for the sake of simplicity, the calculation also ignores level 2 liquid assets). The larger the liquidity requirement, and the lower the yield on level 1 liquid assets, the higher the cost of commercial loans and the larger the bias in favour of lending to governments.

If commercial assets of sufficiently high quality were allowed to count as level 1 liquid assets for LCR purposes alongside deposits in central banks and government securities, then the yield on such assets would be related to $r_{L}$ rather than $r_{D}$ and $\theta$, and would be lower than $r_{N}$. This would facilitate the flow of credit to companies, including small and medium-sized ones, in return for high-quality assets. ${ }^{28}$

It seems clear that the set of assets which a central bank is willing to buy, or take as collateral, routinely and at fine rates, in its open-market operations ought in logic to be identical to the set of assets which commercial banks can count as level 1 liquid assets. If a central bank is willing to buy assets routinely at fine rates, then they are ipso facto high quality liquid assets. ${ }^{29}$ And if the central bank rejects assets which are deemed by regulators to be level 1 liquid assets when conducting open-market operations, then it is implicitly establishing another, different group of high-quality liquid assets.

As already noted, the specification of the LCR, and the risk-weights that are used for the assessment of capital adequacy, appear to be based on the assumption that domestic-currency government securities are perfectly safe. The fact that they are demonstrably not perfectly safe suggests that the Basel Committee on Banking Supervision accepts that, if the government of a country defaults, the banks domiciled in that country will also fail. Indeed, the BCBS's regulations make it unlikely that any bank could survive the default of its home-country government. A wider definition of level 1 liquid assets would therefore make banks safer, as well as stimulating the flow of credit to the productive sector of the economy.

The Basel capital ratio regime has in the past discriminated only very crudely between commercial loans of varying qualities in the standardised approach: the main criterion has been the

\footnotetext{
28 The same would be the case, as John Whittaker has pointed out to me, if central banks made available a facility under which they swapped suitable commercial assets for level 1 liquid assets, such as central bank debt certificates.

29 The use of the word 'routinely' perhaps requires some explanation. What is meant is that offers of the assets in question to the central bank in its regular open-market operations are regarded as normal, and not as conveying any suggestion of distress on the part of the offeror. Of course, the offers may not always be accepted in full, or at all, but that is in the nature of open-market operations.
} 
credit rating of the borrower, factors such as the maturity of the loan being of little account. ${ }^{30}$ All banks, whether they use the standardised or the internal ratings-based approach to risk weighting, will be subject to the all-encompassing capital leverage ratio. There are recent signs, however, of some regulatory recognition of credit quality in the application of the leverage ratio, at least as regards contingent liabilities: for 'short-term self-liquidating trade letters of credit arising from the movement of goods (e.g. documentary credits collateralised by the underlying shipment), a $20 \%$ CCF [credit conversion factor] will be applied to both issuing and confirming banks. 31

A liquidity policy which recognised the intrinsic liquidity of some short-term commercial claims would incentivise banks to generate high quality assets from their commercial customers. And routine purchases of such assets by central banks would be a recognition that the strength of a currency is based not only on the taxing power of the sovereign but on the commercial activity of the country or group of countries which the currency serves. It is important to distinguish between a policy of being willing to buy short-term commercial claims in amounts that the central bank determines by reference to the needs of monetary policy, and the long-discredited 'realbills doctrine', which asserts that as long as central banks confine their asset purchases to selfliquidating bills representing real trade transactions, over-issue of currency is impossible and the central bank may therefore safely purchase without limit.

The bank rescues undertaken in and after 2008 created massive moral hazard, in that even uninsured deposits and bonds were mostly repaid at public expense if the bank was insolvent or illiquid. It was clear that, after that experience, the rules of the banking game would have to change and that much more regulation would be inevitable. The criticisms of the Liquidity Coverage Ratio made in this paper are of its formulation: specifically, that it forces banks to hold government securities or claims on the local central bank which may not be safe, that it ignores commercial assets which may in practice provide good liquidity, and that it thereby implicitly subsidises government borrowing at the expense of commercial borrowing. Broader issues in the regulation of bank liquidity are discussed by Goodhart (2008) and Allen (2010).

It has to be admitted that there is no evidence that the large-scale purchases of commercial bills by the Bank of England in the 1980s had any effect on the quality of credit. However, the supply of bills at that time reached only $8.3 \%$ of total sterling credit; in those days, commercial lending was growing very fast; and there was no bias in favour of lending to governments of the kind that exists now. It is entirely plausible that, in present circumstances, a policy of treating high-quality short-term commercial claims as liquid assets and of making them eligible for routine central bank purchase on a substantial scale, would generate a considerable revival in high-quality commercial lending.

Central banks would need to make decisions about what price to offer for high-quality commercial claims, relative to government debts, and what quantities to buy. These decisions, which would be inter-related, are likely to raise difficult questions. Central banks will normally want to avoid offering to buy assets of any particular type at a yield that the market clearly regards as too low relative to the yields at which it is willing to buy other eligible assets, so that the market chooses to concentrate its offerings in that particular class. Another, related, objective is to manage and diversify the central bank's portfolio risks. However, if there is a particular policy objective at stake, concentrated offerings and concentrated portfolio risks may be unavoidable. Decisions about the relative pricing of the various assets eligible for purchase in open-market operations need to be adjustable without there being any change in the general level of short-term interest rates that the central bank is trying to maintain.

30 Basel Committee on Banking Supervision (2006, p. 23). The ECB/Bank of England consultative paper on asset-backed securities (2014) suggests that holdings by regulated financial institutions of 'qualifying securitisations', which meet specified minimum quality standards, might benefit from lower capital requirements.

31 Basel Committee on Banking Supervision (2014, p. 19, para 20). 
It is not suggested that commercial bills of exchange are the only private-sector asset worthy of consideration for routine purchase by central banks, or even that they are the most attractive. It is true that commercial bills have the advantage of a well-established legal foundation, not only in the United Kingdom but also in many other countries, thanks to the Geneva Convention of 1930 on bills of exchange and promissory notes. But the commercial bill market has diminished in size and would need to be revived. More important, perhaps, the nature of commerce has developed, as has information technology, and the financing functions that bills of exchange used to perform may now be performed better by other means. The essential features on which central banks should insist in purchasing assets, except in emergencies in which greater risktaking may be acceptable, are short maturities, non-renewability, strong guarantees, simplicity, and an intimate relationship with non-financial trade. The ECB/Bank of England paper of 2014 on securitisation discusses the possible development of markets in asset-backed securities, and soon after the paper appeared, the ECB decided on a new programme for purchasing asset-backed securities. $^{32}$

Notwithstanding the Bank of England's happy, or fortunate, experience in the 1980s, commercial assets undeniably carry some risk. Occasional isolated losses have to be expected, and central banks need enough capital to enable them to carry the risk. They also need strong risk management skills: for example, fraudulent bills were widespread in the $19^{\text {th }}$ century. ${ }^{33}$ More important, there were two major crises in the London bill market in the $20^{\text {th }}$ century. The outbreak of war in 1914 made it impossible for many continental drawers of bills (I.e. borrowers) to repay on time. ${ }^{34}$ The resulting losses were socialised as the Bank of England agreed to rediscount the bills and allow them, exceptionally, to be renewed repeatedly until after the war. And in 1931, the bank failures in Austria, Hungary and Germany led to many bills accepted in London not being repaid when they fell due. This episode did great damage to the accepting houses concerned, and to the finances of their partners, but it did not lead to a systemic crisis, since the large clearing banks had ample supplies of other liquid assets, nor did the banking system require public support. ${ }^{35}$ Equally, though, government securities are not riskless. And a 'deadly embrace' between a banking system which relies for its liquidity on domestic government securities and a government which relies on domestic banks for finance can be dangerously unstable: any banking problem automatically becomes a public finance problem, and vice versa.

\section{CONCLUSIONS}

Diversity of sources of liquidity is a defence against instability, since there are no truly safe assets. Central banks' eligibility policies should be made consistent with liquidity regulation. The admission of high-quality commercial assets both as assets eligible for central bank purchase and as level 1 liquid assets would both promote financial stability and facilitate the availability of bank credit to non-financial companies.

\footnotetext{
Bank of England and European Central Bank (2014), European Central Bank (2014).

See King (1972, chapters III, IV and VII), Elliott (2006). Of course, there have also been plenty of more recent frauds.

Morgan (1952, chapter I), Sayers (1976, vol. 1, chapter 5A, and Appendix 3), Roberts (2013).

Sayers (1976, vol. 2, chapters 17 and 20B), Forbes (1987), James (2001, chapter 2), Accominotti (2012), Diaper (1986), Roberts (1992, 1995).

The episode was one of the main factors causing the United Kingdom to abandon the gold standard, however.
} 


\section{References}

Accominotti, O. (2012), London merchant banks, the central European panic and the sterling crisis of 1931, Journal of Economic History, vol. 72, no 1, pp. 1-43.

Allen, W.A. (2010), Liquidity regulation and its consequences, Central Banking, vol. XXI, no 4, pp. 33-37.

Allen, W.A. (2012), Quantitative monetary policy and government debt management in Britain since 1919, Oxford Review of Economic Policy, vol. 28, no 4, pp. 804-836.

Bagehot, W. (1873), Lombard Street - a description of the money market, London, Kegan Paul, Trench, Trübner \& Co Ltd.

Bank of England and European Central Bank (2014), The case for a better functioning securitisation market in the European Union, retrieved $20^{\text {th }}$ May 2015 from http://www.ecb.europa.eu/pub/pdf/other/ecb-boe_case better_functioning_securitisation_marketen.pdf.

Basel Committee on Banking Supervision (2006), International convergence of capital measurement and capital standards (BCBS 128), Basel.

Basel Committee on Banking Supervision (2013), Basel III: the liquidity coverage ratio and liquidity risk monitoring tools (BCBS 238), Basel.

Basel Committee on Banking Supervision (2014), Basel III leverage ratio framework and disclosure requirements (BCBS 270), Basel.

Braudel, F. (1983), Civilisation and capitalism, $15^{\text {th }}-18^{\text {th }}$ century: the wheels of commerce, London, Collins.

Buiter, W. H. (2014), Central banks: powerful, political and unaccountable? (Discussion paper no 10223), Centre for Economic Policy Research, London.

Churm, R., A. Radia, J. Leake, S. Srinavasan and R. Whisker (2012), The funding for lending scheme, Bank of England Quarterly Bulletin, Q4, pp. 306-318.

Clapham, Sir J. (1944), The Bank of England - a history, 2 vols (including appendices), Cambridge, Cambridge University Press.

Coleby, A.L. (1982), Bills of exchange: current issues in a historical context, Bank of England Quarterly Bulletin, pp. $514-518$.

Diaper, S. (1986), Merchant banking in the inter-war period: the case of Kleinwort, Sons \& Co., Business History vol. 26, issue 4, pp. 56-76.

Eichengreen, B. and M. Flandreau (2010), The Federal Reserve, the Bank of England and the rise of the dollar as an international currency, 1914-39 (BIS Working Paper no 328), Basel, Bank for International Settlements.

Elliott, G. (2006), The mystery of Overend and Gurney, London, Methuen.

European Central Bank (2014), Press release, 2 October 2014 -ECB announces operational details of asset-backed securities and covered bond purchase programmes, and 2 annexes, retrieved $20^{\text {th }}$ May 2015 from https:// www.ecb.europa.eu/press/pr/date/2014/html/pr141002_1.en.html.

Forbes, N. (1987), London banks, the German standstill agreements and "economic appeasement" in the 1930s, Economic History Review, vol. 40, no 4, pp. 571-587.

Galati, G. and R. Moessner (2013), Macroprudential policy - a literature review, Journal of Economic Surveys, vol. 27 , no 1 , pp. 846-878.

Goodfriend, M. (2011), Central banking in the credit turmoil: an assessment of Federal Reserve practice, Journal of Monetary Economics, vol. 58, issue 1, pp. 1-12.

Goodhart, C.A.E. (2008), Liquidity risk management, Banque de France Financial Stability Review no 11, special issue on liquidity.

Gregory, T.E. (1929), Select statutes documents and reports relating to British banking, 1832-1928, vol. 1, Oxford, Oxford University Press.

House of Commons Treasury Committee (2012), Uncorrected transcript of oral evidence to be published as HC1867, $29^{\text {th }}$ February, retrieved $20^{\text {th }}$ May 2015 from http://www.publications.parliament.uk/pa/cm201012/cmselect/ cmtreasy/uc1867/uc186701.htm.

Howson, S, (1975), Domestic monetary management in Britain 1919-1938, Department of Applied Economics Occasional Paper 48, Cambridge, Cambridge University Press.

Jobst, C. and S. Ugolini (2014), The coevolution of money markets and monetary policy, 1815-2008 (ECB working paper no 1756), Frankfurt-am-Main, European Central Bank.

King, W.T.C. (1972), A history of the London discount market, London, Cass.

Meulendyke, A.-M. (1998), U.S. monetary policy and financial markets, New York, Federal Reserve Bank of New York.

Morgan, E.V. (1952), Studies in British financial policy, 1914-1925, London, Macmillan.

Roberts, R. (1992), Schroders: Bankers and Merchants, London, Macmillan. 
Roberts, R. (1995), The Bank and the City, in: Roberts, R. and Kynaston, D. (eds), The Bank of England: Money, Power and Influence, 1694-1994, Oxford, Oxford University Press.

Roberts, R. (2013), Saving the City, Oxford, Oxford University Press.

Sayers, R.S. (1936), Bank of England operations 1890-1914, London, P.S. King.

Sayers, R.S. (1957), Central banking after Bagehot, Oxford, Oxford University Press.

Sayers, R.S. (1976), The Bank of England, 1891-1944, 2 vols and appendices, Cambridge, Cambridge University Press.

Sheppard, D.K. (1971), The growth and role of U.K. financial institutions, 1880-1962, London, Methuen.

Stella, P. (2009), The Federal Reserve System balance sheet - what happened and why it matters, (IMF Working Paper WP/120), Washington D.C., International Monetary Fund.

Usher, A.P. (1914), The origin of the bill of exchange, Journal of Political Economy, vol. 22 no 6, pp. $566-576$.

Viner, J. (1937), Studies in the theory of international trade, London, George Allen \& Unwin.

Warburton, C. (1952), 'Monetary difficulties and the structure of the monetary system', Journal of Finance, vol. VII, no 4, pp. 523-545.

Whale, P.B. (1944), A retrospective view of the Bank Charter Act of 1844, Economica, vol. 11, no 43, pp. $109-111$. Ziegler, P. (1988), The sixth great power: Barings 1762-1929, London, Collins. 